\title{
KONSENTRASI SPASIAL, AGLOMERASI DAN PRODUKTIVITAS PERUSAHAAN INDUSTRI MANUFAKTUR INDONESIA
}

\author{
Spatial Concentration, Agglomeration and Firm-Level Productivity in Indonesian \\ Manufacturing Industry
}

Kusuma Wardani'1), M. Halley Yudhistira2)

Universitas Indonesia, Program Pascasarjana IImu Ekonomi, Depok, 16424, Indonesia

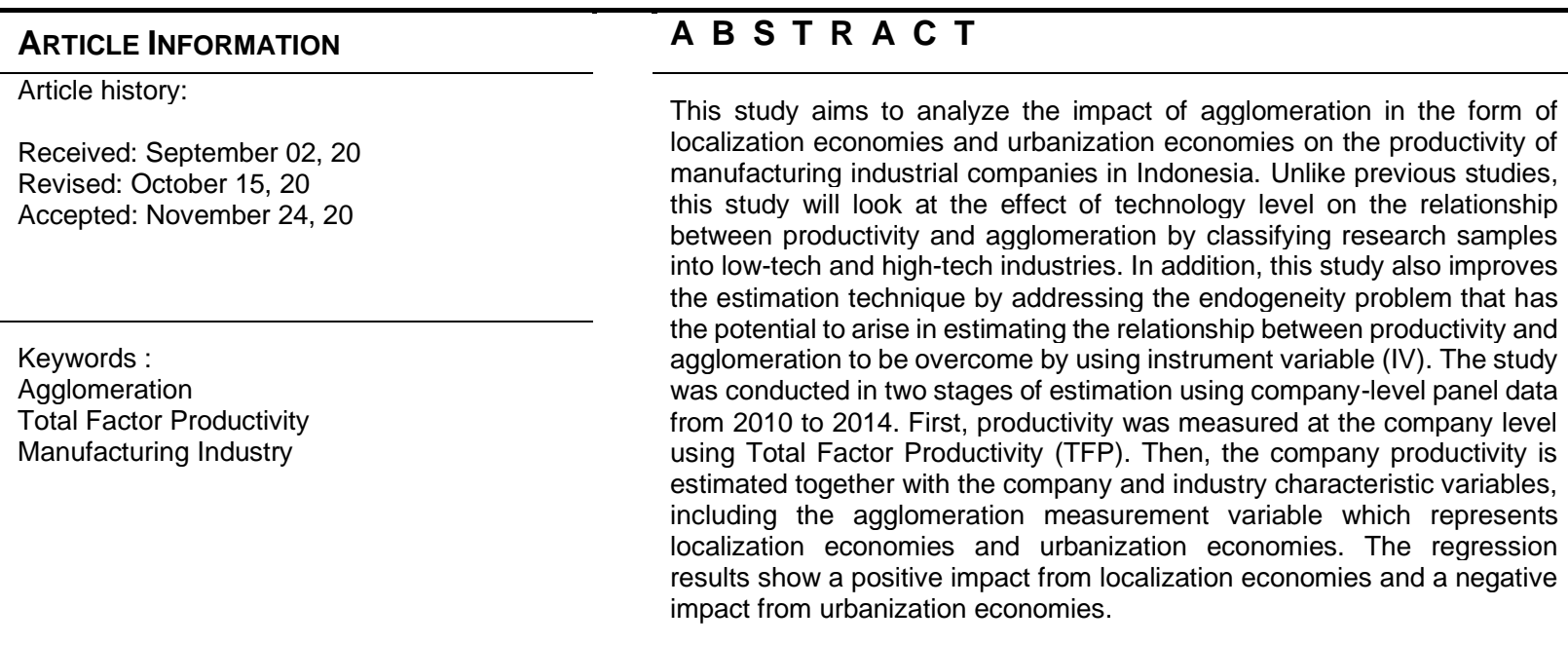

\section{A B S T R A K}

Kata Kunci :

Aglomerasi

Total Factor Productivity

Industri Manufaktur

\footnotetext{
${ }^{*}$ Corresponding Author

Name : Kusuma Wardani

E-mail: wardani.kusuma@gmail.com
}

Penelitian ini bertujuan menganalisis dampak aglomerasi berupa localization economies dan urbanization economies terhadap produktivitas perusahaan industri manufaktur di Indonesia. Berbeda dengan penelitian terdahulu yang juga meneliti dampak aglomerasi industri terhadap produktivitas perusahaan, pada penelitian ini akan melihat pengaruh tingkat teknologi terhadap hubungan produktivitas dan aglomerasi dengan mengklasifikasikan sampel penelitian ke dalam industri berteknologi rendah dan industri berteknologi tinggi. Selain itu, peneltian ini juga memperbaiki teknik estimasi dari penelitian sebelumnya dengan menangani masalah endogenitas yang berpotensi muncul dalam mengestimasi hubungan produktivitas dan aglomerasi akan diatasi dengan penggunaan instrument variable (IV). Penelitian dilakukan dalam dua tahap estimasi dengan menggunakan data panel level perusahaan dari tahun 2010 sampai 2014. Pertama, produktivitas diukur pada level perusahaan dengan menggunakan Total Factor Productivity (TFP). Kemudian, produktivitas perusahaan diestimasi bersama variabel karakteristik perusahaan dan industri, termasuk variabel pengukuran aglomerasi yang mewakili localization economies dan urbanization economies. Hasil regresi menunjukkan adanya dampak positif dari localization economies dan dampak negatif dari urbanization economies.

This is an open access article under the CC-BY license.

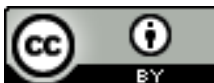

(C) 2020 Some rights reserved 


\section{PENDAHULUAN}

Konsentrasi aktivitas perekonomian di beberapa wilayah telah menjadi fenomena umum yang tejadi baik di negara berkembang maupun negara maju. Berdasarkan perspektif spasial, fenomena ini disebut sebagai keuntungan aglomerasi[1][2]. Keuntungan aglomerasi dapat diartikan sebagai eksternalitas yang muncul dari konsentrasi perusahaan-perusahaan atau industri-industri pada suatu lokasi. Keuntungan aglomerasi biasanya diestimasi dari penurunan biaya atau peningkatan produktivitas yang terjadi pada perusahaan-perusahaan atau industri-industri pada wilayah aglomerasi[3][4][5]. Hal tersebut terjadi sebagai akibat penghematan biaya transaksi atau produksi, pengumpulan tenaga kerja terampil, serta limpahan informasi dan teknologi (knowledge spillovers).

Banyak penelitian yang telah dilakukan untuk mempelajari aktivitas produksi yang terjadi pada wilayah aglomerasi. Hal tersebut terutama dipicu oleh kesuksesan Silicon Valley di Amerika Serikat dan kemunculan teori New Economic Geography[6]. Konsep eksternalitas aglomerasi terdiridari dua jenis, yaitueksternalitas MarshallArrow-Romer (eksternalitas MAR) dan eksternalitas Jacob yang juga didefinisikan sebagai bentuk spesialisasi dan keberagaman[7]. Inti dari pembagian konsep tersebut adalah untuk menentukan sumber limpahan teknologi berasal dari sektor industri sejenis atau sektor industri yang beraneka ragam, serta bagaimana peranan kompetisi dalam mempengaruhi limpahan teknologi tersebut.

Teori mengenai keuntungan eksternalitas tersebut telah menggiring fokus studi empiris tentang aglomerasi dan pertumbuhan produktivitas untuk memisahkan eksternalitas aglomerasi[8], yaitu eksternalitas spesialisasi atau lokalisasi yang berasal dari industri itu sendiri (eksternalitas MAR) dengan eksternalitas yang berasal keberagaman aktivitas ekonomi atau variasi industri (eksternalitas Jacobs). Isu ini penting dalam studi pengembangan perkotaan[9].

Jika industri cenderung kepada eksternalitas MAR, produsen akan lebih memilih membentuk klaster bersama di beberapa kota yang tidak terlalu besar dengan spesialisasi pada jenis komoditi tertentu atau aktivitas ekonomi yang sejenis.Spesialisasi perusahaan akan memaksimalkan keuntungan eksternalitas yang diperolehnya walaupun di sisi lain dapat berdampak pada timbulnya kemacetan dan naiknya harga sewa tanah di daerah tersebut.
Biasanya beberapa akitivitas manufaktur yang terstandarisasi seperti industri tekstil, pengolahan makanan, baja dan produk olahan kayu cenderung akan berkumpul di daerah area perkotaan kecil yang terspesialisasi [10][11].

Di sisi lain, produsen pada industri yang cenderung kepada eksternalitas Jacobs, akan lebih memilih berada di lingkungan yang lebih luas dan beragam. Seperti halnya industri informasi dan teknologi biasanya akan beroperasi di wilayah perkotaan yang lebih luas. Karakteristik eksternalitas akan dipengaruhi pengembangan produk[8]. Pada tipe produk musiman, aktivitas eksperimental akan cenderung ditemukan di daerah perkotaan yang luas dan beragam. Sedangkan pada produk yang terstandarisasi akan berada di daerah yang lebih kecil dan terspesialisasi.

Penelitian mengenai dampak aglomerasi dan produktivitas perusahaan telah dilakukan di Indonesia. Seperti penelitian [12] yang meneliti dampak aglomerasi hanya pada empat kelompok industri pengolahan saja. Hasil penelitian menunjukkan bahwa localization economies lebih berpengaruh positif pada produktivitas perusahaan.Namun pada penelitian ini belum melihat pengaruh teknologi terhadap produktivitas perusahaan.

Berdasarkan penjelasan di atas, penelitian ini bertujuanmenganalisis dampak aglomerasi berupa localization economies dan urbanization economies terhadap produktivitas perusahaan industri manufaktur di Indonesia, khususnya Pulau Jawa. Berbeda dengan penelitian terdahulu yang dilakukan oleh [12]dan [13]yang juga meneliti dampak aglomerasi industri terhadap produktivitas perusahaan, pada penelitian ini akan melihat pengaruh tingkat teknologi terhadap hubungan produktivitas dan aglomerasi dengan mengklasifikasikan sampel penelitian ke dalam industri berteknologi rendah dan industri berteknologi tinggi. Selain itu, peneltian ini juga memperbaiki teknik estimasi dari penelitian sebelumnya dengan menangani masalah endogenitas yang berpotensi muncul dalam mengestimasi hubungan produktivitas dan aglomerasi akan diatasi dengan penggunaan instrument variable (IV). 


\section{METODE PENELITIAN}

\subsection{Sumber Data}

Penelitian ini menggunakan data yang berasal dari Survei Tahunan Perusahaan Industri Manufaktur yang dilakukan oleh Badan Pusat Statistik (BPS)[14]. Darisurvei industri pengolahan diperoleh data pada level perusahaan yang berupa nilai output, tenaga kerja, modal, status kepemilikan modal dan ekspor dari tahun 2010 sampai dengan 2014.Pada penelitian ini dipilih subsektor industri pengolahan (KBLI) 2-digit sebagai agregasi level sektordan kabupaten/kota sebagai agregasi level wilayah. Dikarenakan penelitian ini hanya mengambil studi kasus Pulau Jawa, maka hanya menggunakan data-data perusahaan yang terletak pada seluruh provinsi di Pulau Jawa. Terdapat 22 subsektor industri pengolahan dan 117 kabupaten/kota yang dianalisis pada penelitian ini. Pemilihan data di pulau Jawa dapat digunakan sebagai representasi data industri manufaktur di Indonesia sebagaimana dilakukan oleh [12]dan[13] karena 90 persen perusahaan industri manufaktur berada di Pulau Jawa.

Pembersihan data (cleaning) diperlukan sebelum melakukan estimasi, yaitu dengan cara memilih data perusahaan yang tetap bertahan dan tidak berpindah sektor industri serta lokasi sepanjang waktu observasi, sehingga diperoleh jumlah observasi yang tetap setiap tahun sebanyak 15.485 perusahaan.

\subsection{Operasional Variabel dan Spesifikasi Empiris}

Penelitian ini terdiri dari satu variabel terikat dan beberapa variabel bebas. Variabel terikat yang digunakan adalah Total Factor Productivity (TFP). Sedangkan variabel bebas dikelompokkan menjadi variabel utama dan variabel kontrol.

Estimasi dampak dari aglomerasi terhadap pertumbuhan TFP dalam penelitian menggunakan dua tahap pendekatan. Pertama, melakukan estimasi TFP. Kedua, melakukanregresi pertumbuhan produktivitas tiap perusahaan terhadap variabel karakteristik industri dan perusahaan, serta hasil pengukuran aglomerasi yang mewakili efek dari localization economies dan urbanization economies. Selain itu, penelitian ini menggunakan metode regresi data panel dengan menggabungkan metode time series dan cross section. Data panel tersebut diestimasi dengan metode pooled least squares, random effect dan two-stages least squares.
Pengukuran TFP perusahaan diawali dengan estimasi fungsi produksi Cobb-Douglas sebagai berikut :

$Y_{i j t}=\beta_{0}+\beta_{k} k_{i j t}+\beta_{l} l_{i j t}+\beta_{m} m_{i j t}+\varepsilon_{i j t}$

dimana $y_{i j t}$ :logaritma natural gross output perusahaan $i$ pada sektor industri $j$ pada tahun $t$; $k_{i j t}, l_{i j t}, m_{i j t}$ : logaritma natural nilai modal tetap, jumlah tenaga kerja, dan nilai bahan baku perusahaan $i$ pada sektor industri $j$ pada tahun $t$; dan $\varepsilon_{i j t:}$ error.

Persamaan di atas diregresi untuk memperoleh nilai koefisien dari variabel $k, l$, dan $m$. Variabel $\varepsilon_{i j t}$ mencerminkan residual. Dengan demikian, setelah nilai $\beta_{k}, \beta_{l}$, dan $\beta_{m}$ diketahui, maka nilai TFP perusahaan dapat dihitung melalui persamaan sebagai berikut :

$T F P_{i j t}=y_{i j t}-\hat{\beta}_{k} k_{i j t}-\hat{\beta}_{l} l_{i j t}-\hat{\beta}_{m} m_{i j t}$

Fokus perhatian dalam penelitian ini adalah menganalisis dampak aglomerasi terhadap produktivitas, sehingga variabel utama yang digunakan adalah variabel aglomerasi sebagai berikut:

a. Localization economiessebagai variabel untuk menganalisis eksternalitas intra industri. Spesialisasi diukur dengan location quotient(LQ)[15], yang dapat didefinisikan sebagai share tenaga kerja industri $i$ relatif terhadap total tenaga kerja industri di wilayah jberbanding terbalik dengan share dari tenaga kerja di wilayah $j$ relatif terhadap total tenaga kerja di industri $i$. Pada penelitian ini industri direpresentasi oleh KBLI 2-digit, yang mencakup 22 sub sektor industri dan wilayah dikur pada level kabupaten/ kota yang meliputi 117 kabupaten/ kota. Indeks spesialisasi regional relatif terhadap komposisi industri nasional dapat dituliskan sebagai berikut:

$$
L Q_{i j}^{S}=\frac{s_{i j}^{S}}{s_{i *}}=\frac{x_{i j} / x_{* j}}{x_{i *} / x_{* *}}, i=1, \ldots, I .
$$

$L Q_{i j}$ adalah representasi spesialisasi industri $i$ di wilayah $j$ relatif terhadap spesialisasi industri $i$ pada wilayah agregat.

b. Urbanization economiessebagai variabel untuk menganalisis eksternalitas antar industri. Beberapa indeks pengukuran dapat diaplikasikan untuk mewakili keberagaman wilayah. Pada penelitian ini pengukuran keberagaman wilayah menggunakan invers dari indeks keberagaman HirschmanHerfindahl. Pendekatan ini paling banyak digunakan pada penelitian empiris 
sebelumnya. Indeks tersebut diformulasikan sebagai berikut:

$$
D I V_{j}^{A}=1 / \sum_{i=1}^{I}\left(s_{i j}^{S}\right)^{2}
$$

dimana nilai $D I V_{j}^{A}$ sama dengan I (jumlah industri dalam klasifikasi industri), tenaga kerja sektor industri di wilayah j terdistribusi ke seluruh industri.

Sementara itu, variabel kontrol yang digunakan dalam penelitian ini merupakan faktor input dan eksternal dari masing-masing perusahaan seperti halnya dengan penelitian [16], yaitu:

a. Ukuran perusahaan (SIZE) diukur dari jumlah output riil yang dihasilkan perusahaan. Variabel ini diharapkan mempunyai dampak positif terhadap produktivitas, artinya semakin besar jumlah produksi yang dihasilkan maka produktivitas semakin meningkat. Variabel ini juga merepresentasikan economies of scale.

b. Intensitas modal dihitung dari rasio modal dengan jumlah tenaga kerja untuk masingmasing perusahaan.

c. Dummy status kepemilikan modal, yakni dummy $=1$ jika perusahaan berstatus kepemilikan modal dalam negeri (PMDN) dan dummy $=0$ jika perusahaan berstatus kepemilikan modal asing (PMA). Variabel dummy status kepemilikan berusaha untuk menangkap efek kemampuan manajerial. Apakah perusahaan yang kepemilikannya didominasi pihakasing lebih baik daripada perusahaan domestik atau sebaliknya.

d. Dummy ekspor, dummy $=1$ jika perusahaan melakukan ekspor produk, sedangkan dummy = 0 jika perusahaan tidak melakukan ekspor produk. Variabel dummy ekspor digunakan untuk melihat dampak partisipasi dalam perdagangan internasional[16][17].

Pada penelitian ini, estimasi dampak aglomerasi dituliskan dalam spesifikasi empiris sebagai berikut:

$$
T F P_{i j t}=b_{1} l o c_{i t}^{s j}+b_{2} d i v_{t}^{s j}+b_{3} s i z e_{i t}+b_{4}{ }^{c a p i n} n_{i t}+b_{5} D E K S_{i t}+b_{6} D S T A T_{i t}+\varepsilon_{i t}
$$

dimanaTFP : Total Factor Productivity; loc : localization economies(indeks spesialisasi); urb : urbanization economies(indeks keberagaman); size : ukuran perusahaan; capin : intensitas modal; DEKS : dummy ekspor; DSTAT : dummy status kepemilikan modal; $\varepsilon$ : error; i : perusahaan; $\mathrm{j}$ : sektor; s : wilayah; dan $\mathrm{t}$ : tahun.

\section{HASIL DAN PEMBAHASAN}

\subsection{Hasil Estimasi}

Estimasi tahap pertama adalah penghitungan TFP sebagai proxy produktivitas perusahaan pada sektor industri manufaktur di Indonesia yang diawali dengan menentukan koefisien dari variabel nilai output $(\ln \mathrm{Y})$, nilai kapital $(\ln \mathrm{K})$, jumlah tenaga kerja ( $\ln \mathrm{L})$, dan nilai material ( $\ln \mathrm{M}$ ) dalam sebuah fungsi produksi.

Tabel 1. Hasil Estimasi TFP

\begin{tabular}{lcc}
\hline \multicolumn{3}{c}{ Dependent variable: natural log output (In Y) } \\
& Pooled LS & Random Effect \\
\hline Capital natural log & $0.0177^{* * *}$ & $0.0113^{* * *}$ \\
(In K) & $0.0022^{* * *}$ & 0.0028 \\
Natural log & $0.1578^{* *}$ & $0.1954^{* * *}$ \\
workforce (In L) & $0.0084^{* * *}$ & 0.0103 \\
Log natural raw & $0.9731^{* * *}$ & $0.8484^{* * *}$ \\
materials (In M) & 0.0031 & 0.0028 \\
Constants & $0.1023^{* *}$ & $1.7283^{* * *}$ \\
& 0.0423 & 0.0423 \\
Observation & 77425 & 77425 \\
Adjusted R ${ }^{2}$ & 0.6940 & 0.6938 \\
\hline
\end{tabular}

Ket: Tanda * menunjukkan tingkat signifikansi: * $p<0.1$; ** $\mathrm{p}<0.05 ;{ }^{* * *} \mathrm{p}<0.01$

Pada Tabel 1 ditampilkan hasil estimasi TFP dengan metode pooled least squares dan random effect. Berdasarkan kedua hasil estimasi terlihat bahwa koefisien dari nilai material dan jumlah tenaga kerja lebih besar dibandingkan dengan koefisien dari nilai kapital. Hal ini menunjukkan bahwa bahwa industri manufaktur di Indonesia masih sangat bergantung pada bahan baku dan lebih mengandalkan tenagakerja manusia dibandingkan penggunaan teknologi tinggi dalam proses produksinya.

Pada tahap kedua, hasil estimasi TFP digunakan sebagai variabel dependen dan diestimasi bersama-sama dengan variabel aglomerasi dan variabel kontrol. Estimasi dilakukan dengan membandingkan metode pooled least square dengan random effect. Pada model regresi, terdapat potensi masalah endogenitas dikarenakan adanya reverse causality antara aglomerasi dan produktivitas yang dapat mengakibatkanbiasnya hasil estimasi. Oleh sebab itu,penelitian ini juga menggunakan metode twostage least square dengan menambahkan instrument variable untuk mengatasi masalah endogenitas dalam mengestimasi dampak aglomerasi terhadap produktivitas. Pada variabel aglomerasi localization economies digunakan instrument variable jarak antar daerah ke pusat pertumbuhan ekonomi. Sedangkan pada variabel aglomerasi urbanization economies digunakan 
instrument varible berupa lag 3 tahun dari indeks keberagaman. Hasil estimasi dapat dilihat pada tabel berikut tabel 2 .

Tabel 2.Hasil Estimasi Dampak Aglomerasi terhadap Produktivitas

\begin{tabular}{|c|c|c|c|c|}
\hline \multicolumn{5}{|c|}{ Dependent Variable: TFP } \\
\hline & $\begin{array}{l}\text { Pooled } \\
\text { LS }\end{array}$ & $\begin{array}{c}\text { Random } \\
\text { Effect }\end{array}$ & TSLS (IV) & $\begin{array}{l}\text { GSLS } \\
\text { RE (IV) }\end{array}$ \\
\hline $\begin{array}{l}\text { LOC } \\
\text { (localization } \\
\text { economies) }\end{array}$ & $\begin{array}{l}0.0034 \text { * } \\
(0.0019)\end{array}$ & $\begin{array}{l}0.0013 \text { * } \\
(0.0025)\end{array}$ & $\begin{array}{c}0.6593 \\
\star * * \\
(0.2414)\end{array}$ & $\begin{array}{l}-0.1062 \\
(0.2495)\end{array}$ \\
\hline $\begin{array}{l}\text { DIV } \\
\text { (urbanization } \\
\text { economies) }\end{array}$ & $\begin{array}{c}0.0055 \\
\star \star \star \\
(0.0002)\end{array}$ & $\begin{array}{l}0.0031^{* * *} \\
(0.0002)\end{array}$ & $\begin{array}{c}-0.0433 \\
\star * \\
(0.0184)\end{array}$ & $\begin{array}{c}0.0225 \\
(0.0310)\end{array}$ \\
\hline $\begin{array}{l}\text { SIZE(the size } \\
\text { of the firm) }\end{array}$ & $\begin{array}{c}0.3221 \\
\star \star \star \\
(0.0045)\end{array}$ & $\begin{array}{c}0.4421^{\star * *} \\
(0.0045)\end{array}$ & $\begin{array}{c}0.3138 \\
\star \star \star \\
(0.0060)\end{array}$ & $\begin{array}{c}0.4602 \\
(0.0054)\end{array}$ \\
\hline $\begin{array}{l}\text { CAPINT(capital } \\
\text { intensity) }\end{array}$ & $\begin{array}{c}-0.1579 \\
\star \star \star \star \\
(0.0088)\end{array}$ & $\begin{array}{l}-0.1099 \\
* * \star \\
(0.0094)\end{array}$ & $\begin{array}{c}-0.1329 \\
\star \star * \star \\
(0.0166)\end{array}$ & $\begin{array}{l}-0.0968 \\
\star \star \star \star \\
(0.0100)\end{array}$ \\
\hline $\begin{array}{l}\text { Dummy } \\
\text { Exports }\end{array}$ & $\begin{array}{l}-\underset{* \star *}{-3405} \\
(0.0168)\end{array}$ & $\begin{array}{l}-\underset{* * *}{0.2984} \\
(0.0245)\end{array}$ & $\begin{array}{l}-1.1694 \\
\star \star \star \\
(0.3017)\end{array}$ & $\begin{array}{l}-0.1833 \text { * } \\
(0.0969)\end{array}$ \\
\hline $\begin{array}{l}\text { Dummy } \\
\text { Ownership } \\
\text { Status }\end{array}$ & $\begin{array}{c}0.4924 \\
\star \star \star \\
(0.0315)\end{array}$ & $\begin{array}{c}0.3289 * \star \star \\
(0.3688)\end{array}$ & $\begin{array}{c}0.3444 \\
\star \star \star \\
(0.7598)\end{array}$ & $\begin{array}{c}0.1357 \\
\star \star \\
(0.0626)\end{array}$ \\
\hline Constants & $\begin{array}{l}-5.2699 \\
\star \star \star \\
(0.0954)\end{array}$ & $\begin{array}{l}-5.2126 \\
\star \star \star \\
(0.0661)\end{array}$ & $\begin{array}{l}-5629^{* * *} \\
(0.2060)\end{array}$ & $\begin{array}{c}-5.1813 \\
\star \star \star \\
(0.1187)\end{array}$ \\
\hline Observation & 77425 & 77425 & 77425 & 77425 \\
\hline Adj. $R^{2}$ & 0.3291 & 0.4979 & 0.5708 & 0.4656 \\
\hline $\begin{array}{l}\text { Prob } \\
\text { (F-statistic) }\end{array}$ & 0.0000 & & 0.0000 & \\
\hline $\begin{array}{l}\text { Wald F } \\
\text { Statistic }\end{array}$ & & & 7567 & \\
\hline
\end{tabular}

Ket: Tanda * menunjukkan tingkat signifikansi: * $p<0.1$; ** $p<0.05 ;{ }^{* * *} p<0.01$

Hasil regresi dengan Two-Stages Least Squares (TSLS) menunjukkan bahwa semua variabel bebas secara bersama-sama berdampak secara signifikan terhadap TFP. Hal tersebut dapat dilihat dari nilai F-statistic yang signifikan pada $\alpha=1$ persen. Berdasarkan nilai t-statistic, secara parsial, semua variabel bebas berdampak secara signifikan terhadap variabel tidak bebas. Variabel localization economies secara signifikan berpengaruh positif terhadap TFP suatu perusahaan. Dari hasil regresi diperoleh elastisitas TFP terhadap localization economies adalah 0,6098 , yang menunjukkan jika jumlah tenaga kerja perusahaan lain yang bergerak pada subsektor industri dan berlokasi pada kabupaten/kota yang sama meningkat sebesar 1 persen, dengan asumsi variabel-variabel lain yang juga mempengaruhi produktivitas tenaga kerja dianggap tetap (ceteris paribus), secara TFP suatu perusahaan akan meningkat sekitar 0,6098 persen. Hasil tersebut sejalan dengan penelitian [1] [16].

Keberadaan perusahaan lain yang berlokasi secara berdekatan dan memproduksi barang yang sama menyebabkan timbulnya eksternalitas positif yang diterima oleh suatu perusahaan. Konsentrasi perusahaan-perusahaan yang bergerak pada bidang yang sama pada suatu wilayah menyebabkan pemasok bahan baku dan konsumen produknya juga berlokasi pada wilayah tersebut, sehingga terjadi penghematan biaya transportasi bahan baku dan biaya distribusi produk. Konsentrasi industri juga menyebabkan berkumpulnya tenaga kerja dengan keahlian yang sama pada wilayah tersebut. Hal tersebut menimbulkan kemudahan dalam mendapatkan tenaga kerja terampil, sehingga biaya perekrutan dan pelatihan dapat ditekan. Terlebih lagi jika perusahaan akan melakukan ekspansi, kebutuhan tenaga kerja dalam waktu yang cepat akan terpenuhi. Faktor eksternalitas ketiga adalah limpahan informasi dan teknologi. Transfer informasi antar perusahaan lebih cepat terjadi karena kedekatan lokasi, baik yang diperoleh secara ilegal, melalui pertemuan bisnis, maupun perpindahan tenaga kerja antar perusahaan, sehingga perusahaan dapat mempelajari kinerja perusahaan lain yang bergerak pada bidang yang sama dan memanfaatkannya untuk memperbaiki atau menambah performa perusahaan tersebut. Ketiga eksternalitas tersebut menyebabkan perusahaan mengalami skala ekonomis sehingga produktivitasnya meningkat.

Penelitian ini menggunakan variabel keberagaman (urbanization economies) untuk menganalisis pengaruh yang diterima dari keberagaman atau keseragaman industri terhadap produktivitas suatu perusahaan.

Variabel keberagaman ternyata justru berpengaruh negatif menurunkan produktivitas secara signifikan. Elastisitas TFP terhadap keberagaman industri yaitu sebesar $-0,6012$. Hasil estimasi variabel keberagaman pada penelitian sebelumnya memang menunjukkan hasil yang berbeda. Penelitian [12]yang juga mengambil obyek penelitian di Pulau Jawa tetapi pada periode waktu 1990-2003, urbanization economies yang diproksikan dengan indeks keberagaman berpengaruh positif terhadap TFP walaupun elastisitasnya lebih kecil dari varibel localization economies. Sedangkan pada penelitian [13]yang mengambil obyek penelitian di seluruh Provinsi di Indonesia pada periode waktu 2001-2009, urbanization economies atau keberagaman justru berpengaruh negatif namun tidak signifikan terhadap produktivitas. Selain itu, pengaruh negatif dari eksternalitas Jacob terhadap produktivitas ditemukan dalam hasil penelitian[18], sedangkan dalam penelitian [9] [19]menunjukkan pengaruh positif. 
Menurut eksternalitas Jacobs, keberagaman industri pada suatu wilayah akan menimbulkan transfer informasi dan pengetahuan yang beragam. Keragaman ide dan pengetahuan tersebut dapat menyebabkan munculnya suatu penemuan baru yang dapat digunakan untuk mendukung proses produksi yang berlainan. Sedangkan industri manufaktur di Indonesia masih dalam tahap pembangunan dimana proses R\&D belum terlalu berkembang dan produktivitas masih didominasi faktor skala ekonomi yang didapatkan dari spesialisasi. Selain itu,di Indonesia industri-industri yang berbeda belum mempunyai keterkaitan secara dekat. Penemuan yang dihasilkan pada industri tertentu belum banyak yang dapat digunakan untuk mendukung proses produksi industri lain dikarenakan sebagian besar industri masih menggunakan teknologi rendah, sehingga proses transfer pengetahuan antar industri yang berbeda belum terjadi.

Pada penelitian ini juga akan dilakukan estimasi dampak aglomerasi terhadap produktivitas berdasarkan level teknologi yang digunakan industri tersebut. Klasifikasi industri dilakukan berdasarkan klasifikasi intensitas teknologi industri dari OECD (klasifikasi dapat dilihat pad apendiks). Sehingga dalam penelitian ini dapat dibandingkan dampak aglomerasi pada industri teknologi rendah (low-tech) dan industri teknologi tinggi (high-tech). Hasil estimasi berdasarkan level teknologi dapat dilihat pada tabel berikut.

Tabel 3.Hasil Estimasi Dampak Aglomerasi terhadap Produktivitas berdasarkan Level Teknologi (OECD)

\begin{tabular}{|c|c|c|c|c|}
\hline \multicolumn{5}{|c|}{ Dependent Variable: TFP } \\
\hline & \multicolumn{2}{|c|}{ Low Tech } & \multicolumn{2}{|c|}{ High Tech } \\
\hline & TSLS (IV) & $\mathrm{RE}(\mathrm{IV})$ & TSLS (IV) & $\mathrm{RE}(\mathrm{IV})$ \\
\hline \multirow{2}{*}{$\begin{array}{l}\text { LOC } \\
\text { (localization } \\
\text { economies) }\end{array}$} & $0.9424^{* * *}$ & -0.0480 & -0.6658 ** & -0.9258 \\
\hline & $(0.3316)$ & $(0.2812)$ & $(0.2801)$ & $(1.1198)$ \\
\hline \multirow{2}{*}{$\begin{array}{l}\text { DIV } \\
\text { (urbanization } \\
\text { economies) }\end{array}$} & -0.0650 & 0.0266 & 0.0104 & 0.0554 \\
\hline & $(0.0254)$ & $(0.0669)$ & $(0.0180)$ & $(0.1264)$ \\
\hline \multirow{2}{*}{$\begin{array}{l}\text { SIZE } \\
\text { (the size of } \\
\text { the firm) }\end{array}$} & $0.3176^{* * *}$ & $0.4800^{* * *}$ & $\underset{* \star * \star}{0.2818}$ & 0.3794 \\
\hline & $(0.0071)$ & $(0.0107)$ & $(0.0157)$ & $(0.0178)$ \\
\hline \multirow{2}{*}{$\begin{array}{l}\text { CAPINT } \\
\text { (capital } \\
\text { intensity) }\end{array}$} & $-\underset{* \star \star}{0.1244}$ & $\underset{\star \star \star}{-0.0858}$ & $-\underset{* \star \star}{0.1604}$ & -0.1440 \\
\hline & $(0.0247)$ & $(0.0133)$ & $(0.0252)$ & $(0.4479)$ \\
\hline \multirow[t]{2}{*}{$\begin{array}{l}\text { Dummy } \\
\text { Exports }\end{array}$} & -1.7563 & -0.2116 * & $-\underset{* \star \star}{0.2170}$ & 0.0372 \\
\hline & $(0.4865)$ & $(0.1249)$ & $(0.0621)$ & $(0.1347)$ \\
\hline \multirow{2}{*}{$\begin{array}{l}\text { Dummy } \\
\text { Ownership } \\
\text { Status }\end{array}$} & $-0.2041^{* *}$ & -0.0592 & $-0.3735^{* *}$ & -0.2544 \\
\hline & $(0.2584)$ & $(0.0668)$ & $(0.2750)$ & $(0.6044)$ \\
\hline \multirow[t]{2}{*}{ Constants } & $\underset{* \star \star}{-5.4486}$ & $-\underset{* \star \star}{-5.5006}$ & -2.4599 & -2.2139 \\
\hline & $(0.1375)$ & $(0.5851)$ & $(0.6654)$ & (1.6335) \\
\hline
\end{tabular}

\begin{tabular}{|c|c|c|c|c|}
\hline Observation & 67206 & 67206 & 10219 & 10219 \\
\hline Prob (F-stat) & 0.0000 & 0.0000 & 0.0000 & 0.0000 \\
\hline $\begin{array}{l}\text { Wald F } \\
\text { Statistic }\end{array}$ & 5955 & & 8800 & \\
\hline $\begin{array}{l}\text { Stock-Yogo } \\
\text { weak ID test } \\
\text { critical } \\
\text { values: }\end{array}$ & & & & \\
\hline & 7:03 & & 7:03 & \\
\hline $\begin{array}{l}15 \% \max \\
\text { size IV } \\
20 \% \max \end{array}$ & $4: 58$ & & $4: 58$ & \\
\hline $\begin{array}{l}20 \% \text { max } \\
\text { size IV }\end{array}$ & 3.95 & & 3.95 & \\
\hline $\begin{array}{l}25 \% \max \\
\text { size IV }\end{array}$ & 3.63 & & 3.63 & \\
\hline
\end{tabular}

Hasil regresi dengan Two-Stages Least Squares (TSLS) menunjukkan bahwa semua variabel bebas secara bersama-sama berdampak secara signifikan terhadap TFP. Hal tersebut dapat dilihat dari nilai F-statistic yang signifikan pada $\alpha=1$ persen. Berdasarkan nilai t-statistic, secara parsial, hampir semua variabel bebas berdampak secara signifikan terhadap variabel tidak bebas. Pada industri teknologi rendah, variabel localization economies, urbanization economies, ukuran perusahaan, intensitas modal, status ekspor, berdampak secara signifikan terhadap TFP pada level signifikansi $\alpha=1$ persen. Sedangkan variabel status kepemilikan modal berdampak signifikan terhadap TFP pada level signifikansi $\alpha=5$ persen. Pada industri teknologi tinggi, variabel ukuran perusahaan, intensitas modal, status ekspor, berdampak secara signifikan terhadap TFP pada level signifikansi $\alpha=$ 1 persen. Sedangkan variabel localization economies dan status kepemilikan modal berdampak signifikan terhadap TFP pada level signifikansi $\alpha=5$ persen. Sementara variabel urbanization economies tidak berdampak signifikan terhadap TFP.

\subsection{Pembahasan}

Variabel localization economies secara signifikan berdampak positif terhadap TFP suatu perusahaan. Hasil regresi menunjukkan elastisitas TFP terhadap localization economiessebesar 0,6593, yang berarti jika jumlah tenaga kerja perusahaan lain yang bergerak pada subsektor industri dan berlokasi pada kabupaten/kota yang sama meningkat sebesar 1 persen, dengan asumsi ceteris paribus(variabel-variabel lain yang mempengaruhi produktivitas tenaga kerja dianggap tetap), maka TFP suatu perusahaan akan meningkat pula sebesar 0,6593 persen. Hal tersebut sejalan dengan hasil penelitian[1][12]. 
Pada industri berteknologi rendah, localization economies berdampak positif terhadap TFP. Hasil regresi memperlihatkan elastisitas TFP terhadap localization economies di industri teknologi rendah sebesar 0.9424 . Hal ini menunjukkan bahwa industri berteknologi rendah lebih sesuai melakukan spesialisasi dari suatu produk yang tersandarisasi di suatu wilayah dengan ruang lingkup yang lebih kecil dikarenakan tingkat produktivitasnya masih bergantung terhadap economies of scale yang diperoleh dari keuntungan dari eksternalitas spesialisasi. Sedangkan pada industri berteknologi tinggi, variabel localization economies justru berdampak negatif terhadap TFP. Hasil regresi menunjukkan elastisitas TFP terhadap localization economies pada industri teknologi tinggi sebesar -0.6658 . Kedekatan dengan perusahaan lain yang sejenis pada industri berteknologi tinggi justru akan memungkinkan terjadi kebocoran informasi yang mendorong terjadinya proses imitasi dari perusahaan lain sehingga justru akan mengurangi produktivitas perusahaan[20].

Penelitian ini menggunakan variabel keberagaman (urbanization economies) untuk menganalisis dampak yang diterima dari keberagaman atau keseragaman industri terhadap produktivitas suatu perusahaan. Variabel keberagaman ternyata justru berdampak negatif menurunkan produktivitas secara signifikan. Elastisitas TFP terhadap keberagaman industri yaitu sebesar $-0,0433$.

Hasil estimasi variabel keberagaman pada penelitian sebelumnya memang menunjukkan hasil yang berbeda. Dalam penelitian [12] yang turutmenjadikan Pulau Jawa sebagai objek penelitian pada periode waktu 1990-2003, indeks keberagaman yang digunakan sebagai proksi urbanization economies berdampak positif terhadap TFP walaupun elastisitasnya lebih kecil dari varibel localization economies. Sedangkan pada penelitian [13]yang mengambil objek penelitian di seluruh Provinsi di Indonesia pada periode waktu 2001-2009, urbanization economies atau keberagaman justru berdampak negatif namun tidak signifikan terhadap produktivitas. Selain itu, dampak negatif dari eksternalitas Jacob terhadap produktivitas ditemukan dalam hasil penelitian [18], sedangkan dalam penelitian [19]menunjukkan dampak positif.

Pada industri berteknologi rendah, urbanization economies juga berdampak negatif terhadap produktivitas. Hasil regresi pada industri teknologi rendah menunjukkan elastisitas TFP terhadap urbanization

economiessebesar- 0.0650 .

Sedangkan pada industri teknologi tinggi, variabel urbanization economies tidak berdampak signifikan terhadap TFP.

Ukuran perusahaan dipilih sebagai salah satu variabel kontrol untuk menjelaskan dampak karakteristik perusahaan terhadap produktivitas. Hasil estimasi variabel ukuran perusahaan berdampak positif secara signifikan terhadap produktivitas perusahaan dengan elastisitas sebesar 0,3138. Perusahaan besar cenderung memiliki akses pasar yang lebih baik, manajemen yang lebih profesional, danrespon perubahanyang lebih tanggap dalam dunia bisnis. Selain itu, perusahaan yang memproduksi dalam skala besar melahirkan kondisi economies of scale, dimana biaya per satuan produk yang dijual semakin menurun seiring tingkat produksi yang semakin besar. Perusahaan yang mencapai skala ekonomi akan lebih efisien dikarenakan terjadinya penghematan dalam biaya produksi yang turut memicu peningkatan produktivitas perusahaan[21].

Intensitas modal merupakan salah satu variabel kontrol dalam model estimasi yang digunakan dalam penelitian ini. Salah satu sumber yang sangat penting dalam produktivitas adalah pertumbuhan persediaan modal yaitu jumlah modal total yang tersedia untuk digunakan dalam produksi. Kenaikan modal berarti mesin yang lebih banyak dan lebih baik, sehingga setiap pekerja dapat memproduksi lebih banyak output untuk setiap jam kerja.

Hasil regresi menunjukkan intensitas modal berdampak negatif secara signifikan terhadap produktivitas suatu perusahaan. Elastisitas TFP terhadap intensitas modal sebesar $-0,1329$, yang artinya jika modal per tenaga kerja meningkat 1 persen (ceteris paribus), maka produktivitas suatu perusahaan akan turun 0,1329 persen. Hal tersebut tidak senada dengan hasil penelitian [11]dan [22]dimana rasio modal terhadap tenaga kerja yang lebih tinggi mengakibatkan produktivitas yang lebih tinggi. Hal ini dikarenakan industri manufaktur di Indonesia masih didominasi oleh industri yang bersifat labour intensive yang mnggunakan teknologi rendah. Dengan demikian, penambahan kapital tidak dapat meningkatkan produktivitas.

Hipotesis learning-by-exporting menyatakan bahwa perusahaan memperoleh informasi ketika melakukan ekspor dan menggunakan informasi 
tersebut untuk meningkatkan produktivitas perusahaan[23][24][25]. Model teoritis yang dibangun menunjukkan bahwa suatu perusahaan akan memperoleh keuntungan dari ekspor karena perusahaan tersebut dapat mempelajari dan mengadopsi metode produksi terbaik yang diperoleh dari klien internasional dan kompetitor. Dalam hal ini terjadi eksternalitas dalam bentuk limpahan pengetahuan. Selain itu, perusahaan tersebut juga dapat meningkatkan kemampuan dalam penawaran produk sebagai akibat dari interaksi yang dilakukan dengan klien internasional yang beragam dan mempunyai standar yang tinggi[26].

Variabel dummy ekspor pada penelitian ini secara signifikan menunjukkan perusahaan-perusahaan yang melakukan ekspor produk secara rata-rata mempunyai produktivitas yang lebih rendah daripada perusahaan-perusahaan yang tidak melakukan ekspor. Hal ini menunjukkan belum terjadinya proses learning-by-exporting pada industri manufaktur di Indonesia. Sebagian besar industri manufaktur Indonesia masih menggunakan teknologi rendah dan dikelola secara tradisional sehingga eksternalitas berupa limpahan pengetahuan dari klien internasional belum berjalan baik.Menurut Newman (2017), negara yang proses learning-by-exporting belum berjalan dengan baik dikarenakan masih kurangnya dukungan pemerintah terhadap perusahaan untuk masuk ke dalam pasar ekspor dan perlunya investasi dalam R\&D untuk memastikan adanya proses pembelajaran dari ekspor yang dilakukan untuk peningkatan produktivitas perusahaan, sebagaimana yang terjadi di vietnam dimana ekspor menjadi salah satu kunci sukses pembangunan dan bisa mendapatkan efek pembelajaran kumulatif dari ekspor yang dilakukan[27].

Estimasi variabel status kepemilikan modal menghasilkan dampak positif secara signifikan. Hal ini menegaskan bahwa rata-rata tingkat produktivitas perusahaan dengan status kepemilikan dalam negeri (PMDN) lebih tinggi dibandingkan perusahaan dengan status kepemilikan asing (PMA). Hal tersebut diduga investasi asing lebih banyak terkonsentrasi pada industri yang berteknologi rendah. Industri di Indonesia sebagian besar bergerak pada sektor yang dapat memenuhi kebutuhan pokok, seperti industri makanan, minuman, dan tekstil yang merupakan industri dengan teknologi rendah. Selain itu, kemampuan untuk melakukan penyerapan teknologi oleh pelaku industri lokal masih rendah, sehingga mengalami kesulitan dalam menerima teknologi maju yang dibawa oleh perusahaan asing. Menurut[17], Perusahaan Modal Asing sering memiliki kendala dalam penyesuaian dengan kondisi pasar lokal terutama yang berkaitan dengan sisi kebijakan pemerintah dalam hal infrastruktur, sumber daya manusia dan aglomerasi industri yang terkadang tidak sejalan dengan nilai perusahaan induk. Sehingga status kepemilikan asing tidak berpengaruh positif terhadap produktivitas. Pada penelitian selanjutnya dapat dilakukan pengujian lebih lanjut mengenai dampak status kepemilikan modal perusahaan terhadap produktivitas.

\section{KESIMPULAN}

Hal-hal yang layak dikembangkan berdasarkan hasil penelitian yang telah disajikan sebelumnya sebagai berikut.

a. Pada penelitian ini, pengelompokan industri yang sejenis pada suatu wilayah memberikan pengaruh positif terhadap produktivitas perusahaan. Hasil tersebut menunjukkan bahwa kebijakan klaster industri tepat diterapkan karena dapat meningkatkan produktivitas perusahaan-perusahaan dalam klaster tersebut. Kebijakan klaster industri dapat dikembangkan lagi dengan memperkuat kelembagaan klaster seperti pembentukan lembaga manajemen klaster yang bertugas untuk mengatur dan mengkoordinasi anggota-anggota klaster, baik industri inti klaster maupun industri terkait dan penunjangnya.

b. Konsentrasi industri yang tidak saling berkaitan juga memberi pengaruh positif terhadap produktivitas masing-masing perusahaan pada setiap wilayah. Oleh karena itu, kawasan industri diperlukan untuk makin meningkatkan efisiensi dan produktivitas tiap perusahaan. Kawasan industri perlu didukung dengan infrastruktur dan layanan yang mendukung kegiatan produksi seperti kemudahan akses bahan baku dan distribusi, fasilitas pengolahan air, serta kepastian pasokan energi seperti listrik dan gas. Pemerintah juga telah mengeluarkan peraturan untuk mengatur kawasan industri di Indonesia. Pada peraturan tersebut ditetapkan perusahaan-perusahaan yang baru berdiri diharuskan berlokasi di kawasan industri.

c. Kebijakan untuk mendorong industri pengolahan dalam negeri agar menciptakan merk sendiri sehingga lebih fokus dalam berkompetisi. Saat ini kebanyakan 
perusahaan di Indonesia hanya merupakan subkontraktor dari pemilik merk asing sehingga hanya melakukan produksi sesuai dengan pesanan konsumen. Dengan mempunyai merk sendiri, perusahaanperusahaan akan selalu terpacu untuk mengembangkan inovasi sehingga menghasilkan produk yang berkualitas tinggi dan mampu bersaing di pasar lokal maupun internasional.

d. Meningkatkan penanaman modal asing pada sektor industri pengolahan terutama untuk industri teknologi tinggi atau capital intensive karena industri tersebut mempunyai produktivitas yang tinggi. Kebijakan ini perlu didukung dengan iklim investasi yang kondusif, seperti jaminan keamanan bagi orang asing, kepastian pelaksanaan peraturan daerah yang sejalan dengan peraturan pusat, dan kemudahan perijinan

e. Meningkatkan volume perdagangan internasional karena perdagangan internasional merupakan salah satu metode untuk mengadopsi teknologi baru yang berasal dari negara lain, antara lain dengan meningkatkan ekspor barang-barang produksi industri pengolahan. Cara yang dapat dilakukan adalah memperbanyak penyelenggaraan event internasional di dalam negeri seperti pameran produk lokal Indonesia agar perusahaan lokal mempunyai pengetahuan terhadap pesaing, mendapatkan pemasok/pembeli asing, dan mendapat jaringan internasional yang lebih luas.

Namun, penelitian ini masihmemiliki beberapa keterbatasan yang dapat dijadikan sebagai ruang perbaikan pada penelitian selanjutnya, yaitu antara lain:

a. Hasil survei tahunan oleh Badan Pusat Statistik (BPS) terhadap perusahaan industri pengolahan di Indonesia masih banyak mengandung data dan observasi yang kosong. Oleh sebab itu, penelitian ini hanya mengambil sampel data perusahaan yang lengkap sepanjang waktu pengamatan dan diharapkansudah cukup mewakili keseluruhan populasi.

b. Beberapa studi empiris mengenai aglomerasi telah menggunakan ekonometrika spasial dengan memasukkan unsur jarak antar perusahaan maupun jarak antar wilayah geografis untuk melihat sejauh mana jangkauan dari eksternalitas aglomerasi terjadi. Dikarenakan keterbatasan data, pada penelitian ini belum menggunakan pendekatan tersebut.

\section{DAFTAR PUSTAKA}

[1] P. Martin, T. Mayer, F. Mayneris, P. Martin, T. Mayer, and F. Mayneris, "Spatial concentration and plant-level productivity in France," J. Urban Econ., vol. 69, no. 2, pp. 182-195, 2011.

[2] S. Ke, "Agglomeration, productivity, and spatial spillovers across Chinese cities," Ann. Reg. Sci. 2009 451, vol. 45, no. 1, pp. 157-179, Jan. 2009, doi: 10.1007/S00168008-0285-0.

[3] M. Andersson and H. Lööf, "Agglomeration and productivity: Evidence from firm-level data," Ann. Reg. Sci., vol. 46, no. 3, pp. 601-620, 2011, doi: 10.1007/s00168-0090352-1.

[4] A. Ciccone and R. E. Hall, "Productivity and the Density of Economic Activity," Am. Econ. Rev., vol. 86, no. 1, pp. 54-70, 1996, doi: $10.2307 / 2118255$.

[5] C. Hu, Z. Xu, and N. Yashiro, "Agglomeration and productivity in China: Firm level evidence," China Econ. Rev., vol. 33, pp. 50-66, Apr. 2015, doi: 10.1016/j.chieco.2015.01.001.

[6] P. R. Krugman, Krugman, and Paul, "What's New about the New Economic Geography?," Oxford Rev. Econ. Policy, vol. 14, no. 2, pp. 7-17, 1998.

[7] E. L. Glaeser, H. D. Kallal, J. A. Scheinkman, and A. Shleifer, "Growth in Cities," J. Polit. Econ., vol. 100, no. 6, pp. 1126-1152, 1992, doi: 10.1086/261856.

[8] Gilles Duranton and D. Puga, "Microfoundations of Urban agglomeration economies," Handb. Reg. Urban Econ., 2003, Accessed: Jun. 14, 2020. [Online]. Available:

https://www.nber.org/papers/w9931.

[9] C. Beaudry and A. Schiffauerova, "Who's right, Marshall or Jacobs? The localization versus urbanization debate," Res. Policy, vol. 38, no. 2, pp. 318-337, 2009, doi: 10.1016/j.respol.2008.11.010. 
[10] J. V. Henderson, Henderson, and J. Vernon, "Marshall's scale economies," J. Urban Econ., vol. 53, no. 1, pp. 1-28, 2003.

[11] H.-L. Lin, H.-Y. Li, C.-H. Yang, H.-L. Lin, H.-Y. Li, and C.-H. Yang, "Agglomeration and productivity: Firm-level evidence from China's textile industry," China Econ. Rev., vol. 22, no. 3, pp. 313-329, 2011.

[12] A. Kuncoro, "Spatial Agglomeration, Firm Productivity, and Government Policies in Indonesia: Concentration and Deconcentration in the Manufacturing Sector," in Reshaping Economic Geography in East Asia, 2009, pp. 156168.

[13] W. Widodo, R. Salim, and H. Bloch, "Agglomeration economies and productivity growth in manufacturing industry: Empirical evidence from Indonesia," Econ. Rec., vol. 90, no. S1, pp. 41-58, 2014, doi: 10.1111/14754932.12115 .

[14] "IBS."

https://mikrodata.bps.go.id/mikrodata/inde x.php/catalog/IBS (accessed Aug. 15, 2020).

[15] R. Nakamura and C. J. Morrison Paul, "Measuring agglomeration," in Handbook of Regional Growth and Development Theories, Edward Elgar Publishing Ltd., 2009, pp. 305-328.

[16] C. Altomonte and G. Békés, "Trading activities, firms and productivity," Bocconi Univ. Milan, Hungarian ..., no. September, 2008, [Online]. Available: http://test.mktudegy.hu/files/BekesG.pdf.

[17] G. Békés and P. Harasztosi, "Agglomeration premium and trading activity of firms," Reg. Sci. Urban Econ., vol. 43, no. 1, pp. 51-64, 2013, doi: 10.1016/j.regsciurbeco.2012.11.004.

[18] K. Frenken, F. Van Oort, and T. Verburg, "Related variety, unrelated variety and regional economic growth," Reg. Stud., vol. 41, no. 5, pp. 685-697, 2007, doi: $10.1080 / 00343400601120296$.

[19] R. Capello, "Entrepreneurship and spatial externalities: Theory and measurement," in Annals of Regional Science, 2002, vol. 36, no. 3, pp. 387-402, doi: $10.1007 / \mathrm{s} 001680200106$.

[20] T. P. Torres Gutierrez and J. A. Ordóñez, "Agglomeration economies and urban productivity," REGION, vol. 6, no. 1, pp. 17-24, Jan. 2019, doi: 10.18335/region.v6i1.242.

[21] K. Badr, R. Rizk, and C. Zaki, "Firm productivity and agglomeration economies: evidence from Egyptian data," Appl. Econ., vol. 51, no. 51, pp. 55285544, Nov. 2019, doi: 10.1080/00036846.2019.1613506.

[22] Z. G. Tareke, "Estimating the $E$ ect of Urban Environment on Swedish Firm Productivity," 2011.

[23] E. Bbaale, "Firm-level productivity and exporting in Uganda's manufacturing sector," African J. Econ. Manag. Stud., vol. 2, no. 2, pp. 220-242, 2011, doi: $10.1108 / 20400701111165650$.

[24] J. De Loecker, "Detecting Learning by Exporting," Am. Econ. J. Microeconomics, vol. 5, no. 3, pp. 1-21, 2013, doi: 10.1257/MIC.5.3.1.

[25] C. Newman, J. Rand, F. Tarp, and N. T. T. Anh, "Exporting and productivity: Learning from Vietnam,” J. Afr. Econ., vol. 26, no. 1, pp. 67-92, 2017, doi: 10.1093/jae/ejw021.

[26] M. Azari, H. Kim, J. Y. Kim, and D. Ryu, "The effect of agglomeration on the productivity of urban manufacturing sectors in a leading emerging economy," Econ. Syst., vol. 40, no. 3, pp. 422-432, Sep. 2016 , doi: 10.1016/j.ecosys.2015.08.005.

[27] N. Najkar, M. R. Kohansal, and M. Ghorbani, "Impact of Industrial 
Agglomeration on Productivity: Evidence from Iran's Food Industry," Chinese Geogr. Sci., vol. 30, no. 2, pp. 309-323, Apr. 2020, doi: 10.1007/s11769-019-1087-2.

\section{Biografi Penulis}

Kusuma Wardani, SE, M.S.E. adalah seorang PNS pada Ditjen Industri Kecil Menengah dan Aneka Kementerian Perindustrian yang menamatkan pendidikan sarjana dan pascasarjana pada Program Studi IImu Ekonomi Fakultas Ekonomi dan Bisnis Universitas Indonesia (FEB UI). Riset akademik yang telah dirampungkannya berfokus pada bidang Ekonomi Industri.

Muhammad Halley Yudhistira, Ph.D. saat ini

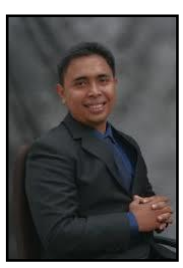
aktif di lingkungan Fakultas Ekonomi dan Bisnis Universitas Indonesia (FEB UI) sebagai Ketua Program Studi Magister Perencanaan Ekonomi dan Pembangunan (MPKP), dosen ilmu ekonomi, managing editor pada Jurnal Ekonomi dan Pembangunan Indonesia (JEPI), serta research fellow pada Lembaga Penyelidikan Ekonomi dan Masyarakat (LPEM). Alumnus FEB UI dan GRIPS Jepang ini telah menghasilkan beberapa penelitian dengan peminatan pada bidang ekonomi regional dan perkotaan, ekonomi transportasi, serta ekonometrika terapan. 